\title{
Genealogia międzynarodowości. Społeczna teoria stosunków międzynarodowych
}

$\mathbf{W}$ ostatnio opublikowanych artykułach, odwołując się przede wszystkim do rozważań teoretycznych Justina Rosenberga, podejmowaliśmy próbę ukazania powodów dychotomizacji „międzynarodowości” i ,wewnętrzności” i sposobów jej przezwyciężenia ${ }^{1}$. Wskazywaliśmy na dwa główne powody tej dychotomizacji na gruncie socjologii historycznej. Pierwszy polegający na niezdolności do sformułowania socjologicznej definicji „międzynarodowości”. Przez „socjologiczną definicję” rozumieliśmy bezpośrednie sformułowanie międzynarodowości jako przedmiotu teorii społecznej. Międzynarodowość powinna być organicznie zawarta w samej koncepcji rozwoju społecznego. Dopóki definicja taka nie istnieje, socjologia historyczna w sposób nieunikniony traktuje zjawisko międzynarodowe jako teoretycznie zewnętrzne. Dlaczego jednak trudno taką definicję sformułować? Drugi powód, i jednocześnie próba odpowiedzi na postawione pytanie, nie wynika $\mathrm{z}$ teorii międzynarodowej per se, ale raczej z tradycji klasycznej teorii społecznej, z której materiał do takiej definicji powinno się czerpać. Siła tej tradycji leży w jej predyscyplinarnej holistycznej ambicji: klasyczni autorzy dążyli do stworzenia całościowych teorii rozwoju społecznego. Jednakże, tradycja ta nigdy nie sformułowała teoretycznie multilinearnego i interaktywnego wymiaru rozwoju społecznego jako zjawiska historycznego.

Również przedstawiciele współczesnej socjologii historycznej nie rozwiązali tego problemu ,ontologicznej pojedynczości”. Trudno bowiem uznać go za rozwiązany poprzez proste dodanie dodatkowej przesłanki o wielości (multiplicity) - społeczeństwa zawsze koegzystowały z innymi społeczeństwami - jak postępują, choć na różne sposoby, Theda Skocpol, Anthony Giddens czy Michael Mann. W ten sposób, w kategoriach teoretycznej procedury, najbardziej zaawansowane prace socjologii historycznej w istocie reprodukują ten sam schemat: jedna teoria wyjaśnia zjawiska wewnętrzne, druga - międzynarodowe ${ }^{2}$.

Niezajmowaną przez socjologię zewnętrzną „ontologiczną pojedynczość” (międzynarodowość) zawłaszczyła dominująca w NSM teoria realizmu politycznego. Realizm polityczny fundował się tym samym w postaci geopolitycznej reifikacji, koncentrując się całkowicie na

\footnotetext{
${ }^{1}$ A. Gałganek, Czy istnieje teoria społeczna ,, międzynarodowości” $i$,, wewnętrzności”?, „Przegląd Politologiczny” 2007, vol. XII, nr 2, s. 21-38; tenże, Abstrakcja nierównego i połaczonego rozwoju w wyjaśnianiu historii stosunków międzynarodowych, „Prawo i Polityka” 2009, vol. 1, nr 1, s. 53-84; tenże, Społeczna teoria stosunków międzynarodowych. Poza dychotomię «międzynarodowości» $i$ «wewnętrzności», w: Metodologia badań politologicznych w Polsce, red. M. Pietraś, K. Marzęda, Wydawnictwo UMCS, Lublin 2009; tenże, Dlaczego nie istnieje teoria spoleczna «międzynarodowości»? Analiza systemów-światów i neorealizm: dwie strony tego samego medalu, „Przegląd Humanistyczny” (w druku).

2 J. Rosenberg, Anarchy in the Mirror of 'Uneven and Combined Development'. An Open Letter to Kenneth Waltz, Paper presented at the British-German IR conference BISA/DVPW 16-18 May 2008 Arnoldshain, Germany, s. 6 .
} 
„Zewnętrzności”. W jego teoretyzacji przedmiotem NSM stało się wyłącznie owo „między”. Zostało to w szczególnie wpływowy sposób utwierdzone w koncepcji realizmu strukturalnego K. Waltza. Państwa, jako aktorzy „między” są funkcjonalnie niezróżnicowane, a ich dążące do izomorfizmu zachowanie jest skutkiem wymogów, jakie stawia przed nimi anarchicznie zorganizowany system międzynarodowy. Jednak, mimo podkreślania konieczności rozróżniania między zjawiskami poziomu międzynarodowego i poziomu jednostkowego stanowisko Waltza nie było nigdy doktryną rzeczywistej separacji obu poziomów. Dla Waltza procesy zachodzące na poziomie jednostkowym są zarazem źródłem zmian w systemie, jak i możliwych zmian samego systemu ${ }^{3}$. Co więcej, mimo iż radzi on badaczom stosunków międzynarodowych koncentrowanie się na odrębnych teoriach wewnętrznej i międzynarodowej polityki, należy tak postępować dopóki nie znajdzie się ktoś kto zdoła oba poziomy zintegrować w jedna teorię ${ }^{4}$.

Problem „międzynarodowości” i „,wewnętrzności” nie zostanie zatem przezwyciężony, dopóki niedokończona praca klasyków nie znajdzie swego zakończenia, to znaczy dopóty teoria społeczna nie obejmie tych własności społecznej egzystencji, które generują zjawisko „międzynarodowości”, . Potrzebujemy zatem takiej koncepcji społeczeństwa, którego emergentną (nieredukowalną) własnością jest ,międzynarodowość”. Tylko wtedy „międzynarodowość" nie będzie traktowana jako zjawiska suprasocjologiczne wprowadzane post hoc do koncepcji świata społecznego ${ }^{6}$.

Czego brakuje klasycznej teorii społecznej? Pytanie Rosenberga będące tytułem jego pracy Why is There No International Historical Sociology? nawiązuje bezpośrednio do pytania Wighta Why is There No International Theory? Rosenberg mówiąc o klasycznej teorii społecznej wskazuje na teoretyzowanie w XVIII i XIX wieku. Ocena powstałych wówczas koncepcji teoretycznych, pozwala na sformułowanie wniosku podobnego do tezy M. Wighta. Żaden z wielkich klasycznych teoretyków społecznych nie włączył w systematyczny sposób faktu między-społecznej koegzystencji i interakcji („,międzynarodowości”) do swojej teoretycznej koncepcji społecznej przyczynowości. Ani do wyjaśniania tworzenia się społecznych porządków, ani do wyjaśniania dynamiki procesów ich historycznego rozwoju.

Rosenberg zadaje pytanie: dlaczego? Jeśli różnica i zmiana mogą być teoretyzowane, dlaczego nie interakcje i ich rola w wytwarzaniu tej różnicy i zmiany? W klasycznej tradycji socjologicznej możemy znaleźć dynamiczne teorie wewnętrznej zmiany w czasie historycznym (sekwencję: starożytne, średniowieczne i nowożytne formy społeczeństwa); komparatywne teoretyzacje różnicy między kulturami (kontrastujące europejskie struktury społeczne z otomańskimi, indyjskimi i chińskimi). To czego nie znajdziemy, to połączenie dynamiki wewnętrznej zmiany i komparatywnych elementów analizy różnic między kulturami w celu teoretyzowania o specyficznie między-społecznym wymiarze zmiany społecznej. Wniosek Rosenberga jest tożsamy z wnioskiem Wighta dotyczącym międzynarodowej teorii politycznej. Po prostu, nie ma klasycznej socjologicznej teorii ,,międzynarodowości ", .

\footnotetext{
${ }^{3}$ K. N. Waltz, Interview with Ken Waltz. Conducted by Fred Halliday and Justin Rosenberg, ,Review of International Studies" 1998, vol. 24, s. 380.

${ }^{4}$ K. N. Waltz, Reflections on ,, Theory of International Politics”: a response to my Critics, w: Neorealism and its Critics, ed. R. Keohane, Columbia University Press, New York 1986, s. 340.

5 J. Rosenberg, Why is There No International Historical Sociology?, „European Journal of International Relations", Sep. 2006, vol. 12, nr 3, s. 307-308.

${ }^{6}$ J. Rosenberg, Anarchy..., op. cit., s. 6.

${ }^{7}$ J. Rosenberg, Why..., op. cit., s. 312.
} 
Brak klasycznej socjologicznej teorii „międzynarodowości” wpływa na współczesne badania stosunków międzynarodowych. Z punktu widzenia socjologii historycznej obserwujemy w rezultacie podstawowy metodologiczny rozdział między socjologicznymi i geopolitycznymi (Rosenberg określa w ten sposób dominujący sposób teoretyzowania w NSM) eksplanacjami. Socjologiczne, koncentrują się na naturze społeczeństw; geopolityczne, na warunkach generowanych przez ich koegzystencję. Próbie przerzucenia między nimi mostu przez stronę socjologiczną zarzuca się ,redukcjonizm” fundowany na ocenie jej niezdolności do wyjaśniania geopolitycznych imperatywów prowadzących do różnych form społeczeństw. I odwrotnie, ten sam argument jest formułowany przeciwko NSM, której brakuje jakiejkolwiek ogólnej teorii rozwoju społecznego, co prowadzi do reifikacji międzynarodowości.

\section{Czy istnieje teoria społeczna „międzynarodowości” i „wewnętrzności”?}

Według Rosenberga ukazanie społecznej ontologii stosunków międzynarodowych nie jest szczególnie trudnym zadaniem. Wiemy, że między konkurencyjnymi teoriami stosunków międzynarodowych od dziesięcioleci toczy się w tej kwestii spór. Rosenberg definiuje opisowo „międzynarodowość” jako wymiar społecznej rzeczywistości wyrastający z koegzystencji wewnątrz niej, więcej niż jednej społeczności ${ }^{8}$. Z tej prostej definicji wynikają jednak co najmniej trzy istotne implikacje. Po pierwsze, jeśli ludzkie społeczności zawsze koegzystowały z innymi, prowadzi to do wniosku, że w społecznym świecie zawsze istniał między-społeczny obszar wielokierunkowości i zróżnicowania, którego funkcjonowania nie można wyprowadzać in toto z wewnętrznych odrębności składających się nań społeczeństw. Stanowisko takie zajmują w szczególności zwolennicy realizmu politycznego, dla których „międzynarodowość” jest zjawiskiem transhistorycznym. Po drugie, z faktu, że wszystkie społeczeństwa stawały przed „obliczem zewnętrznego świata”, z którym musiały sobie radzić, wynika, że imperatyw ten oddziaływał na warunki indywidualnej reprodukcji tych społeczeństw. Prowadzi to do wniosku, że rozwój społeczny jest nie tylko wielokierunkowy, ale także interaktywny i współzależny. Po trzecie, z okoliczności tych wynika, że wewnętrzne wzorce rozwoju mogą być przerywane przez zewnętrzne wydarzenia, determinowane i przekształcane przez zewnętrzne presje, przyspieszane lub opóźniane przez rezultaty rozwoju innych społeczeństw. W społecznym świecie składającym się z więcej niż jednego społeczeństwa, nie tylko może się tak stać, ale nieustannie się tak dzieje, co musi być traktowane jako istotna okoliczność dla konceptualizowania samego rozwoju jako zjawiska historycznego. W konsekwencji, wszystkie społeczeństwa w swojej ewolucji podlegają skutkom ich koegzystencji z innymi społeczeństwami. Ta między-społeczna koegzystencja wprowadza wielokierunkowość i interaktywność do samego pojęcia „społeczeństwo”. Obraz „kulturowej mozaiki”, w której każda kultura miałaby stanowić jednostkę terytorialną o wyraźnie zarysowanych, trwałych krawędziach - pisze antropolog Ulf Hannerz - nigdy tak naprawdę nie korespondował z rzeczywistością. Zawsze zachodziła interakcja, dyfuzja myśli, zwyczajów i rzeczy, nawet jeśli w pewnym czasie przyzwyczailiśmy się do teorii kultury i społeczeństwa, które tych prawd nie podkreślaty ${ }^{10}$.

\footnotetext{
${ }^{8}$ Ibidem, s. 307-308.

9 J. Rosenberg, International Relations - the „Higher Bullshit”: A Reply to the Globalisation Theory Debate, Post Mortem Forum Reply: IP Submision, 2007, s. 1-2.

${ }^{10}$ U. Hannerz, Powiazania transnarodowe. Kultura, ludzie, miejsca, Wydawnictwo Uniwersytetu Jagiellońskiego, Kraków 2006, s. 33.
} 
Jeśli między-społeczna koegzystencja jest faktem transhistorycznym w społecznym świecie, czy możliwe jest wyjście poza to stanowisko i poszukiwanie alternatywnego punktu wyjścia? Realiści nie zajmują się w szczególny sposób tą kwestią. Dla nich transhistoryczność systemu międzynarodowego jest artefaktem działań społecznych. System międzynarodowy powstał jako rezultat interakcji między zorganizowanymi grupami społecznymi w procesie historycznym, ale w sposób „,mimowolny”. Rosenberg poszukuje charakterystyki, która identyfikowałaby bardziej ogólne cechy rzeczywistości społecznej. Wówczas, między-społeczna koegzystencja byłaby zjawiskiem wewnętrznym tej bardziej ogólnej rzeczywistości społecznej. Jego zdaniem, charakterystyka taka istnieje: społeczny rozwój człowieka jest - i zawsze był-nierówny ${ }^{11}$.

Społeczny rozwój człowieka, widziany całościowo, zawsze składał się z różnorodności typów organizacyjnych, form kulturowych i zajmowanych przez nie skali geograficznych. Przebiegał w różnym tempie i pod kierunkiem różnorodnych form władzy politycznej. W konsekwencji, każdy jednostkowy przykład tego rozwoju koegzystował z innymi, z rozmaitym stopniem oddziaływań, które były znaczące, zarówno dla poszczególnych społeczeństw, jak i kumulatywnego ruchu procesu historycznego jako całości. Z tych dwóch faktów, nierównego i połączonego rozwoju, wyrasta, zarówno istnienie ,międzynarodowości” (lub między-społeczności) jako wymiaru społecznego świata, jak też nieskończona liczba determinant wpływających na konstytuowanie się samej „społeczności”. Nierówność rozwoju znajduje swój wyraz nie tylko w jakościowym zróżnicowaniu jego historycznych form, ale także w ilościowej różnorodności jego przykładów. Teza ta stanowi w istocie podstawową przesłankę każdej międzynarodowej konceptualizacji. Z tej różnorodności form wynika fakt między-społecznej koegzystencji jako uniwersalnego wymiaru rozwoju społeczno-historycznego ${ }^{12}$.

Racjonalizacja ta pozwala zrozumieć „międzynarodowość” jako wyrastającą z wcześniejszego socjologicznego atrybutu samego rozwoju - tkwiącej w nim nierówności. Propozycja ta stanowi istotę odpowiedzi na pytanie czy możliwa jest teoria społeczna łącząca „,międzynarodowość" z ,wewnętrznością"? Tradycja NSM, podobnie jak tradycja socjologii, zawsze konceptualizowały, odpowiednio „stosunki międzynarodowe” i ,społeczeństwo”, jako ontologiczną „pojedynczość”, wykluczając, odpowiednio bądź jedno, bądź drugie, ze swoich teoretyzacji rozwoju. Na gruncie socjologii podejmującej próbę wyjaśniania stosunków międzynarodowych prowadziło to do redukcjonizmu w formie ,wewnętrznej analogii”; na gruncie NSM, w kierunku przeciwnym, do nawet bardziej abstrakcyjnej tezy o międzynarodowej anarchii jako zjawisku suprasocjologicznym. Powodowało to w efekcie sytuację, w której „międzynarodowość” była brakującym ogniwem teorii społecznej; zaś „,wewnętrzność” brakującym ogniwem teorii międzynarodowej. Znajdowało to wyraz w tezie, kognitywnie i normatywnie pozbawionej znaczenia, o cykliczności „nawrotów i powtórek” (M. Wight) ${ }^{13}$.

Rosenberg przejmuje ideę „nierównego i połączonego rozwoju” (dalej NIPR) od Leona Trockiego. Trocki sformułował swoją tezę na początku XX wieku w celu wyjaśnienia znaczącej różnicy między społecznym rozwojem Rosji i prognozami ortodoksyjnego marksizmu. W tezie tej zawarł diagnozę rozwoju kapitalizmu w Rosji, który nie mógł i nie będzie mógł postępować drogą wyznaczoną przez Anglię i Francję. Jest to konsekwencją jego odmiennego socjologicznego punktu wyjścia (wynikającego z wcześniejszego „nierównego

\footnotetext{
${ }^{11}$ J. Rosenberg, International..., op. cit., s. 2.

12 Ibidem, s. 2.

13 Ibidem, s. 3.
} 
rozwoju") i faktu, że przebiega on w warunkach międzynarodowych wcześniej przekształconych przez istnienie bardziej rozwiniętych społeczeństw kapitalistycznych, których wpływ „,połączył się” z wewnętrznymi źródłami rosyjskiego rozwoju. W pismach Trockiego ten lokalny argument zostaje przekształcony w alternatywną teoretyzację rozprzestrzeniania się kapitalizmu jako procesu historycznego. Marksowski homogeniczny świat budowany przez kapitalizm na swoje podobieństwo (Manifest Komunistyczny), w koncepcji Trockiego przekształcił się w wielość niepowtarzalnych wzorców ,połączonego rozwoju”. Idea Trockiego zawiera istotne spostrzeżenie, wykraczające poza problem kapitalistycznego rozwoju, o znaczeniu „międzynarodowości” w ludzkiej historii. Rosenberg dowodzi, że NIPR jest emergentnym składnikiem samego procesu historycznego, a Trocki w ten sposób przezwycięża przeszkody na drodze do socjologicznej definicji „międzynarodowości”,14.

Socjologia prawie zawsze konceptualizowała „społeczeństwo” w jego ontologicznej pojedynczości - wykluczając między-społeczny wymiar ze swoich teoretyzacji rozwoju. NSM zmierzała w przeciwnym kierunku, usuwając społeczeństwo z „między-społeczności”. To „socjologiczne” i ,geopolityczne” podejście doprowadziło do metodologicznie odrębnych logik wyjaśniania. Jednej koncentrującej się na zróżnicowanej naturze społeczeństw, drugiej budowanej wyłącznie na ,nieredukowalnym” fakcie ich uniwersalnej koegzystencji. Proponowane postępowanie jest zatem próbą rozwiązania problemu reifikacji ,międzynarodowości” w formie nadanej jej przez teorię realizmu politycznego (geopolityka) i reifikacji „wewnętrzności” w formie analiz socjologicznych. Można tego dokonać poprzez konstrukcję abstrakcji NIPR jako uniwersalnej (ogólnej) abstrakcji samego procesu historycznego ${ }^{15}$. Fakt, że wszystkie społeczeństwa konfrontują się z zewnętrznym wobec nich światem powoduje, że imperatyw ten staje się warunkiem reprodukcji każdego społeczeństwa. Rozwój społeczny jest nie tylko wielokierunkowy, ale także interaktywny i współzależny. Okoliczności te powodują, że wewnętrzne wzorce rozwoju mogą zostać przerwane przez zewnętrzne wydarzenia, zdeterminowane i przekształcone przez zewnętrzne presje, a także opóźnione lub przyspieszone przez rozwój innych społeczeństw. W świecie składającym się z więcej niż jednego społeczeństwa dzieje się to nieustannie. W tym sensie okoliczność ta musi być traktowana jako nieodłączna od każdej teoretyzacji samego rozwoju jako zjawiska historycznego ${ }^{16}$.

\section{Genealogia międzynarodowości}

Skąd wzięła się „międzynarodowość”? Co odpowiada za jej istnienie jako wymiaru świata społecznego? Justin Rosenberg odwołując się do idei NIPR podejmuje próbę udzielenia odpowiedzi na to pytanie w trzech krokach. Po pierwsze, konstruuje model pozwalający na porównanie różnych sposobów wiązania nierównego rozwoju ze stosunkami międzynarodowymi. Jak się okazuje, jak dotąd, wszystkie te sposoby raczej zakładały istnienie politycznej wielości (międzynarodowości) aniżeli ją wyjaśniały (1). Po drugie, poszukując wyjaśnienia Rosenberg sięga do historyczno-socjologicznego argumentu zawartego w pracy Barry Buza-

\footnotetext{
14 J. Rosenberg, Why..., op. cit., s. 309.

15 A. Callinicos, J. Rosenberg, Uneven and combined development: the social-relational substratum of, ,the international”? An exchange of letters, „Cambridge Review of International Affairs” 2008, vol. 21, nr 1, s. 81.

${ }^{16}$ J. Rosenberg, International Relations: the „, Higher Bullshit”. A Reply to the Globalization Theory Debate, „International Politics", Summer 2007, vol. 44, nr 4, s. 450-482.
} 
na i Richarda Little ${ }^{17}$. Lokują oni źródła międzynarodowości w prehistorycznym przejściu od myśliwsko-zbierackiego do osiadło-rolniczego sposobu życia związanego z procesami społecznego różnicowania ${ }^{18}$ i formowania protopaństw. Wyjaśnienie sformułowane przez Buznana i Little'a na pierwszy rzut oka wydaje się czynić zbędnym odwoływanie się do pojęcia NIPR. Po dokładniejszej analizie Rosenberg odkrywa, że „nierówność” i „połączenie” odgrywają kluczową rolę w ich empirycznej argumentacji, nie stanowiąc jednak przedmiotu teoretyzowania (2). Po trzecie, Rosenberg stara się ukazać jak „nierówność” i ,połączenie” są niezbędnymi elementami procesu społecznej zmiany. Ukazuje w ten sposób, że źródła „międzynarodowości” rzeczywiście znajdują się w nierównym i połączonym charakterze rozwoju historycznego $(3)^{19}$.

\section{(1) Model nierównego i połączonego rozwoju}

Każda próba ustanowienia społecznej teorii stosunków międzynarodowych musi odpowiedzieć na pozornie proste pytanie - dlaczego istnieje wiele społeczeństw? Jaka cecha rozwoju społecznego odpowiada za ten fakt, z którego wynika każde przyczynowe zjawisko określane jako międzynarodowe? Rosenberg określa to pytanie jako „zwodniczo proste”. Mimo że wiele perspektyw teoretycznych przywiązuje wielką uwagę do międzynarodowego wymiaru świata społecznego żadna z nich nie wydaje się konstytuować samego faktu społecznej wielości (societal multiplicity) jako przedmiotu teoretyzowania.

W celu rozwiązania tego problemu Rosenberg wskazuje na trzy możliwe sposoby ustanawiania stosunku wielości do nierówności: 1) zewnętrzny; 2) wewnętrzny i 3) emergentny.

${ }^{17}$ B. Buzan, R. Little, International Systems in World History. Remaking the Study of International Relations, Oxford University Press, New York 2000.

${ }^{18} \mathrm{~W}$ artykule zatytułowanym Differentiation: A sociological approach to international relations theory, B. Buzan i R. Little rozważają problem jak pojęcie zróżnicowania można zastosować do przemyślenia na nowo rozumienia historii systemów międzynarodowych (lub społeczności międzynarodowych) w NSM. W ich interpretacji pojęcie zróżnicowania oferuje potencjalną teorię historii stosunków międzynarodowych. Na perspektywę tę mogą składać się następujące tezy: 1) zróżnicowanie może stanowić pojęcie wiążące NSM i antropologię, a tym samym ułatwiać przejście od dominujących w NSM praktyk myślenia o źródłach stosunków międzynarodowych w kategoriach wyobrażeń europejskich teoretyków politycznych w rodzaju T. Hobbesa, I. Kanta czy J. J. Rousseau, do myślenia w kategoriach współczesnej wiedzy o prehistorii. Powinniśmy poszukiwać odpowiedzi na pytanie, w którym momencie wczesne stadia zróżnicowania doprowadziły do powstania jednostek prowadzących ,stosunki międzynarodowe” i jak stosunki te wpłynęły na wewnętrzne struktury jednostek przekształcających się z formy segmentarnej w stratyfikacyjną; 2) świat starożytny i klasyczny oferują model stosunków międzynarodowych, w którym stratyfikacyjne zróżnicowanie dominuje zarówno na poziomie jednostek (królowie, cesarze, niewolnicy) jak i na poziomie systemu międzynarodowego (nierówny status, imperium) poprzez wiele tysięcy lat w wielu różnych systemach międzynarodowych; 3) w perspektywie zróżnicowania okres średniowiecza miał charakter zarówno stratyfikacyjny (papieże, cesarze, szlachta), jak i funkcjonalnie zróżnicowany (kościoły, gildie). Według Buzana i Little okres średniowiecza jest szczególnie ważny dla NSM, ponieważ poprzedzał porządek westfalski, który narodził się w Europie i został nałożony na resztę świata; 4) charakterystyka starożytnego, klasycznego i średniowiecznego świata może ukazać nam jak zróżnicowanie działa, gdy w grę wchodzą zarówno wewnętrzny, jak i międzynarodowy poziom; wreszcie, 5) pojęcie zróżnicowania może pomóc nam w zrozumieniu przejścia od segmentarno/stratyfikacyjnego westfalskiego systemu międzynarodowego do systemu globalnego, w którym mamy do czynienia z emergencją zróżnicowania funkcjonalnego. W systemie globalnym presja ku funkcjonalnemu zróżnicowaniu pochodzi od tych państw, które są wewnętrznie najbardziej zaawansowane i generuje problemy dla tych państw, których wewnętrzne zróżnicowanie jest mniej zaawansowane. Zob. szerzej B. Buzan, R. Little, Differentiation: A sociological approach to international relations theory, „European Journal of International Relations” 2010, vol. 16, nr 3, s. 332-333.

${ }^{19} \mathrm{~J}$. Rosenberg, Basic problems in theory of uneven and combined development. Part II: unevness and political multiplicity, „Cambridge Review of International Affairs”, March 2010, vol. 23, nr 1, s. 165. 
Stosunek politycznej wielości do nierównego i połączonego rozwoju

\begin{tabular}{||l|l|l||}
\hline Poziom I & zewnętrzny & $\begin{array}{l}\text { Dynamika politycznej wielości determinuje procesy nierównego i połączonego rozwo- } \\
\text { ju z zewnatrz. }\end{array}$ \\
\hline Poziom II & wewnętrzny & $\begin{array}{l}\text { Polityczna wielość, w istocie odwieczna, jest wewnętrznym (choć nieteoretyzowanym) } \\
\text { aspektem nierównego i połączonego rozwoju. }\end{array}$ \\
\hline Poziom III & emergentny & Polityczna wielość wyrasta z nierównej i połączonej jakości społecznego rozwoju. \\
\hline \hline
\end{tabular}

Źródło: J. Rosenberg, Basic problems in theory of uneven and combined development. Part II: unevness and political multiplicity, „Cambridge Review of International Affairs”, March 2010, vol. 23, nr 1, s. 167.

\section{Poziom I: zewnętrzny}

Na pierwszy rzut oka polityczna wielość wydaje się stanowić jeden z wielu wymiarów, poprzez które działa nierówność historycznego rozwoju: poziomy rozwoju, typy społeczeństw, zakres terytorialny, skala demograficzna, historyczne doświadczenie, sytuacja geo-ekologiczna itp. I aczkolwiek relacja ta może wywoływać liczne dramatyczne skutki pozostaje tym niemniej relacją zewnętrznq. Zróżnicowany rozwój pomiędzy społeczeństwami wpływa na rozwój wewnatrz społeczeństw poprzez jego skutki dla politycznych i militarnych stosunków między nimi ${ }^{20}$. Zewnętrzne determinanty realizujące się zwykle poprzez interakcje z bardziej zaawansowanymi sąsiadami przeczą endogenicznej i linearnej konceptualizacji rozwoju. Jednak nierówność społecznego rozwoju, z jednej strony, i kontekst wielości jednostek politycznych, z drugiej strony, są całkowicie oddzielnymi cechami świata społecznego. Na poziomie I zatem, stosunek wielości i nierówności jest zewnętrzny, i nawet przypadkowy. Nierówność rozwoju nabiera dodatkowych przyczynowych właściwości w rezultacie jej refrakcji (zmiany jakiej doświadcza przy przechodzeniu do innego ośrodka) poprzez historycznie daną wielość społeczeństw/jednostek politycznych. Takie rozumienie relacji między nierównością a wielością, mimo iż włącza „międzynarodowość” do teorii rozwoju nie dostarcza socjologicznego wyjaśnienia podstawowej przesłanki teoretycznej realizmu politycznego związanej z samą geopolityczną (międzynarodową) wielością.

\section{Poziom II - wewnętrzny}

W tym rozumieniu polityczna wielość nie jest traktowana w kategoriach jej zewnętrznego wpływu na rozwój, ale jest raczej rozumiana jako jedna z jego wewnętrznych właściwości. Uznanie przez Trockiego nierówności jako najbardziej ogólnego prawa procesu historycznego może stanowić przykład tego sposobu jej rozumienia. Rozwój społeczny nigdy nie był „pojedynczy”. Traktowany światowo, w każdym swoim stadium zawierał zawsze więcej niż jedną realizację. Ta wielość zawsze miała swoje konsekwencje zarówno dla konstytucji, jak i ewolucji poszczególnych porządków społecznych ${ }^{21}$. Na poziomie II międzynarodowa wie-

\footnotetext{
${ }^{20} \mathrm{Na}$ przykład, nierówny ekonomiczny rozwój prowadzi do określonych skutków poprzez presje, jakie wywiera na niezależność słabszych ekonomicznie społeczeństw. Suwerenna władza takich społeczeństw może odpowiadać na te presje poprzez podejmowanie działań skierowanych zarówno do własnego społeczeństwa, jak i wobec zewnętrznych źródeł presji. Zob. J. Rosenberg, Basic..., op. cit., s. 168.

${ }^{21}$ Wyjaśnienia logicznego i empirycznego uzasadnienia wymaga w istocie przeciwna teza znajdująca wyraz $\mathrm{w}$,ontologicznej pojedynczości”. Teza ta jest uznawana jako empirycznie nie do utrzymania i konceptualnie dysfunkcjonalna na różne sposoby: w socjologii jako „metedologiczny nacjonalizm”; w geografii jako „terytorialna pułapka”; w antropologii jako „mit prymitywnej izolacji”; w teorii politycznej jako „,szczególna przychylność wobec państwa narodowego". Zob. J. Rosenberg, Basic..., op. cit., s. 169
} 
lość i towarzysząca jej polityczna wielość są traktowane jako odwieczne i zbyt konsekwencyjne okoliczności, aby można je traktować jedynie jako ,historycznie dany” dodatek do teoretyzacji czym jest rozwój społeczny. Tylko wówczas, gdy międzynarodowa wielość jest generycznie włączona do tej teoretyzacji można klasę determinant wynikającą z faktu wielości włączyć do socjologicznego zjawiska, jakim musi ona ostatecznie być.

Jednak, jak przekonuje Rosenberg, także ten krok, w którym wielość społeczeństw wskutek jej odwiecznego charakteru staje się jedną z właściwości samej nierówności, rozwiązuje jeden problem, prowadząc do powstania nowego. Uznanie, że nierówność zawsze prowadzi do wielości, rodzi pytanie dlaczego tak musi być? Nierówność manifestuje się także w pełni wewnatrz społeczeństw nie zawsze prowadząc do ich politycznej fragmentacji. Jak zatem można jej użyć do wyjaśniania faktu politycznej fragmentacji między społeczeństwami? Jeśli nie odpowie się na to pytanie nie można rościć sobie prawa do uznania międzynarodowości za socjologicznie wyjaśnioną jako wymiar rozwoju. Dylemat ten prowadzi nas do poziomu III ${ }^{22}$.

\section{Poziom III - emergentny}

Na poziomie III Rosenberg nie zakłada istnienia międzynarodowości. Wychodzi tym samym ,poza” jej istnienie w celu postawienia bardziej podstawowego pytania. Nie chodzi bowiem o to jak międzynarodowość determinuje rozwój społeczny, ani o to czy jej istnienie rozciagga się poprzez cały historyczny zasięg rozwoju społecznego, ale raczej dlaczego stanowi ona odwieczną cechę tego rozwoju? Zatem, czy NIPR może stanowić ramę dla udzielenia takiej odpowiedzi?

Rosenberg ustanawia trzy warunki rozwiązania tego problemu. (1) Wśród wielu znaczeń międzynarodowej wielości, to wielość „polityczna” pociąga za sobą koegzystencję wielu społeczności, niż tylko rodzaj regionalnej wariacji w ramach pojedynczej społeczności. Zatem, celem musi być wyjaśnienie tej wielości koegzystujących jednostek politycznych. (2) Ponieważ jej źródła leżą poza dostępnymi danymi historycznymi, żadne jej empiryczne wyjaśnienie nie jest możliwe. Tym niemniej, wyjaśnienie to musi być zgodne z danymi, jakimi obecnie dysponujemy w tej kwestii. (3) Każde wyjaśnienie musi ukazywać poddającą się teoretyzowaniu rolę odgrywaną przez nierówność w konstytuowaniu politycznej wielości.

To są najważniejsze powody skłaniające do traktowania politycznej wielości jako emergentnego wyrazu nierównej i połączonej natury rozwoju, niż tylko przypadkowej determinanty lub odwiecznej, ale niewyjaśnionej jej cechy. Jednak (3) warunek, który wymaga ustanowienia „nierówności” jako teoretycznego założenia uznaje Rosenberg za niemożliwy do spełnienia niejako z definicji. Każdy bowiem wie, że historyczny rozwój jest wieloraki, zróżnicowany i empirycznie nieuporządkowany - że jest nierówny. Czy może zatem być rzeczywiście tak teoretyzowany? Długa tradycja zachodniej myśli społecznej wskazuje, że nie może. Dowodzi się bowiem, że teorię można konstruować w oparciu o regularności i ciągłości, które występują w rzeczywistym świecie. Zatem poprzez abstrahowanie od nieregularności i nieciagłości. Jeśli tak, jak zatem może nierówność funkcjonować jako teoretyczna przesłanka?

Przede wszystkim wydaje się, iż należy oddzielić społeczną wielość, która jest w istocie odwieczna, od politycznej wielości, która taką nie jest. Dopiero w późnym stadium prehistorycznego rozwoju społeczna wielość staje się także polityczną wielością. Jest tak, ponieważ sama polityka jest emergentnym rezultatem procesu społecznego różnicowania, w wyniku

${ }^{22}$ J. Rosenberg, Basic..., op. cit., s. 169-170. 
którego powstają „,społeczeństwa”. Poprzez ukazanie jak NIPR mógł poprzedzać fakt politycznej wielości otwiera się logiczna możliwość jej derywacji.

Rosenberg ukazuje tę możliwość w trzech krokach. W pierwszym wskazuje realno-światowy przedmiot ogólnej socjologicznej koncepcji rozwoju (1). W drugim, ustanawia empiryczną i teoretyczną podstawę przeformułowania politycznej wielości jako nierównej i połączonej (2). W trzecim wreszcie, ukazuje jak taka przeformułowana koncepcja politycznej wielości może zostać użyta do lepszego wyjaśnienia powstania politycznej wielości (3).

\section{(1) Socjologiczna koncepcja rozwoju}

W najszerszym rozumieniu przedmiotem socjologicznej koncepcji ,rozwoju” jest proces zapoczątkowany ok. 250 tys. lat temu w Afryce wschodniej przez przodków współczesnego człowieka, w wyniku którego ludzie rozprzestrzenili się na całej planecie. $\mathrm{Z}$ procesem tym wiąże się także sukcesywny rozwój społecznych i materialnych ludzkich możliwości. W jego wyniku genetyczna jedność gatunku jest przesłaniana przez wzrastającą samoświadomościową interaktywną jedność zróżnicowanych części zajmujących cały glob. Wszyscy wielcy teoretycy społeczni dążyli do ujęcia specyfiki nowożytnych społeczeństw poprzez ustanowienie szerokich koncepcji ludzkiego rozwoju, które obejmowałyby ten proces. Wszyscy charakteryzowali ten proces historycznego rozwoju społecznego sięgając do prehistorycznego stanu ,prymitywnych” społeczeństw. Jednak żaden z nich, czy to K. Marks, M. Weber, czy E. Durkheim, nie włączył explicité w swoją ogólną abstrakcję rozwoju tej klasy między-społecznych (międzynarodowych) determinant, które wyrastały z ich wewnętrznej nierówności. Celem Rosenberga jest zatem usunięcie tego wyłączenia w celu ustanowienia generalizacji, które są niezbędne do teoretyzowania skutków nierówności jako własności historycznego rozwoju ${ }^{23}$. Ludzki produktywny i wyobrażeniowy stosunek do natury był w istocie zawsze kolektywnie organizowany, tworząc równocześnie podstawową matrycę wzajemnych ludzkich stosunków. Ludzka historia z tego punktu widzenia jest następowaniem po sobie kolejnych pokoleń, z których każde dziedziczyło daną konstelację społecznych i naturalnych stosunków i modyfikowało ją poprzez własną (re)produktywną aktywność. Kluczowym rezultatem tej sukcesji jest stopniowe działanie procesu społecznego zróżnicowania (,,podziału pracy”). Akumulacyjny charakter tego procesu znajduje swój wyraz, używając terminologii Erica Wolfa, w następowaniu po sobie zorganizowanych na zasadzie pokrewieństwa, trybutarnych i kapitalistycznych form społeczeństwa. W swej istocie jest to kluczowe klasyczne rozumienie socjologicznej koncepcji rozwoju.

\section{(2) Dlaczego rozwój musi być nierówny i połązony}

Poszukując podstawy uzasadniającej włączenie do tej klasycznej koncepcji rozwoju predykatów „nierówny” i ,połączony” Rosenberg dąży do wykazania, że identyfikują one empiryczne determinanty, które są konstytutywne dla zrozumienia czym jest rozwój jako proces historyczny. Przyczynowe znaczenie tych determinant powoduje, że nie mogą one zostać wykluczone z żadnego wyjaśniania, które aspiruje do bycia prawomocną abstrakcją tego procesu.

Naturalny świat stanowi nie tylko fizyczną podstawę ludzkiego życia, ale jest także, szczególnie w okresie prehistorycznym, najbardziej istotnym źródłem nierównego rozwoju. Klimatyczne, topograficzne i ekologiczne zróżnicowanie geograficznej przestrzeni przedstawia ogromna rozmaitość habitatów, do których ludzkie grupy adaptuja się w procesie rozprze-

\footnotetext{
${ }^{23}$ Ibidem, s. 178.
} 
strzeniania ze swego wschodnioafrykańskiego domu. Rozpiętość tej różnorodności oznacza, że proces ludzkiej adaptacji musi oznaczać bardzo różne rzeczy (w kategoriach zarówno praktycznej znajomości naturalnych procesów, jak $i$,nowych potrzeb” generowanych przez ich wykorzystywanie) w różnych czasach i miejscach-nawet jeśli ludzkie grupy wszędzie podzielaja wspólnq charakterystykę grupy myśliwsko-zbierackiej ${ }^{24}$. Proces zaludniania Ziemi, w znacznym stopniu zrealizowany przez grupy myśliwsko-zbierackie (dalej GMZ), był z konieczności nierówny w czasie i przestrzeni. Nierówność ta wyrażała się w olbrzymim zróżnicowaniu ludzkiej społeczno-ekologicznej adaptacji. Zróżnicowaniu temu towarzyszył jednak od początku jego ,połączony” charakter. Biologiczna reprodukcja GMZ zależała od ich egzogamicznych interakcji z innymi grupami, tworząc sieci pokrewieństwa stanowiące podstawę periodycznych spotkań, podzielanego języka i bezpieczeństwa. Grupy angażowały się także w wymiany, tworząc sieci transmisji przedmiotów i idei na długie dystanse.

Nierówność w formie olbrzymiego zróżnicowania jest zatem koniecznym, a nie przypadkowym, faktem globalnego rozwoju społecznego. Zaś między-społeczne interakcje (połączony rozwój) stanowią najszersze źródło społecznej zmiany w ludzkiej historii. W istocie teoretyzując nierówność rozwoju społecznego nie mówimy o konieczności abstrahowania od partykularności, ale o fakcie samej partykularności i tym co ona obejmuje - zróżnicowanie, wariacje - tym samym właśnie nierówność ${ }^{25}$. Formalizując w koncepcji „rozwoju” socjologiczne zjawiska różnorodności (wariacji) i interaktywności demontujemy jego [...] mono-sekwencyjnq wewnętrzna strukturę - strukturę, która w podstawowym stopniu odpowiada za jego tendencję do generowania wszelkiego rodzaju błędów linearności. To jest ostateczna konceptualna podstawa do traktowania nierówności i połaczoności jako teoretycznych założeñ ${ }^{26}$.

\section{(3) Wyjaśnienie politycznej wielości}

W koncepcji B. Buzana i R. Little sekwencja rozwoju „osiadłość - rolnictwo - jednostki polityczne” stanowi kamień węgielny socjologicznej derywacji „międzynarodowości”27. Kiedy wyjaśniają oni tę sekwencję, nierówny i połączony charakter rozwoju jest już zawarty w ich przyczynowym schemacie. Nie rozwiązuje tego problemu ogólne pojęcie rozwoju oparte wyłącznie na zróżnicowaniu. Takie rozumienie rozwoju odwołuje się do wyjaśnień opartych na faktach, których poszukuje się poprzez teoretyzacje poziomów rozwoju społecznego (oparty na pokrewieństwie, trybutarny, kapitalistyczny). Według Rosenberga dodanie do tego predykatów „nierówny” i ,połączony” nie rozwiązuje tego problemu. Jego rozwiązaniem może być jedynie ogólna koncepcja przyczynowych mechanizmów, które muszą być wewnętrzne wobec empirycznych procesów, które są przedmiotem analizy. Prowadzi to do wzmocnienia eksplanacyjnej siły ogólnego pojęcia rozwoju.

Rosenberg ukazuje to rozpoczynając swoją argumentację od odwołania się do archeologicznych danych sugerujących, że ludzkie osiedla pojawiały się początkowo sporadycznie, w miejscach, gdzie naturalna obfitość pożywienia pozwalała na całoroczne utrzymanie. Miejsc, gdzie taka obfitość obejmowała również pożywne gatunki roślin nadające się do udomowienia, było jeszcze mniej. Liczbę przypadków obejmującą możliwość niezależnych narodzin rolnictwa ocenia się obecnie na mniej niż dziesięć. Prowadzi to do oczywistego wniosku, że rolnictwo jako pierwsze pojawiło się w pewnych miejscach, a w innych nie. Ten

\footnotetext{
${ }^{24}$ Ibidem, s. 180.

${ }^{25}$ Ibidem, s. 181.

${ }^{26}$ Ibidem, s. 182.

${ }^{27}$ B. Buzan, R. Little, International..., op. cit., rozdz. 6 i 7.
} 
element partykularności związany z pojawieniem się rolnictwa ukazuje, że nie był to proces równoczesny ani w czasie, ani w przestrzeni. Podstawowa kwestia, jaka wynika $\mathrm{z}$ tego faktu wiąże się z przyczynową teksturą procesu historycznego. Ukazuje ona, że ogólne zmiany muszą mieć charakter interaktywny, osiągając różne miejsca w różnych czasach. Te przestrzenno-czasowe „wydłużenia” procesu historycznego mają krytyczne znaczenie. Z jednej strony, oznaczają one, że w każdym momencie ogólny wzorzec rozwoju musi uwzględniać nierówny rozkład zarówno form społeczno-kulturowych, jak i materialnych możliwości koegzystujących ludzkich społeczności. Z drugiej strony, ponieważ społeczności te koegzystują i wchodzą w interakcje, uboczna nierówność form i możliwości sama staje się czynnikiem w ich dalszym (,„połączonym”) rozwoju. Tylko z tego powodu społeczno-historyczny rozwój musi być wielolinearny i interaktywny. Obecność przyczynowej struktury międzynarodowości można tym samym przewidywać w przestrzenno-czasowej charakterystyce samego rozwo$j u^{28}$. Buzan i Little demonstrują, że ,międzynarodowość” jest rezultatem rozwoju związanym z narodzinami z czasem ,polityczności”, a zatem nie czymś co można wyprowadzić bezpośrednio z natury samego rozwoju. Aby znaleźć polityczna wielość wyrastającą z procesu NIPR, Rosenberg analizuje trzecie stadium sekwencji rozwoju zakładanej przez Buzana i Little’a - narodziny państwa. Celem tej analizy jest wykazanie, że połączony rozwój odgrywa kluczową rolę w tym powstaniu ,polityczności”.

W argumentacji Buzana i Little'a rola ta jest odnajdywana w sposobie, w jaki osiadła (i rolnicza) egzystencja zmienia interaktywną logikę społecznej reprodukcji i rozwoju. W odróżnieniu od GMZ, podstawowym środkiem zabezpieczania się przed presjami środowiska staje się teraz przejście od mobilnego utrzymywania powiązań z innymi grupami do gromadzenia żywności w stałym miejscu. Zmiana taka nie tylko prowadzi do nowej wrażliwości związanej z działaniami innych grup mającymi na celu zdobycie pożywienia, ale zmienia także przestrzenną logikę bezpieczeństwa - od rozproszenia do nukleacji. Dysponowanie nadwyżką żywności stwarza także nowe role społeczne związane z możliwością jej wymiany z innymi grupami. Z jednej strony, nietrwała żywność może być wymieniana na trwałe dobra luksusowe, które mogą być wymieniane na powrót na żywność w okresie jej niedostatku. Z drugiej strony, wymiana taka przyczynia się do gromadzenia stałego „,bogactwa”, które może służyć także innym celom. Zróżnicowany dostęp do prestiżowych dóbr odgrywa znaczącą rolę w konsolidacji wewnętrznej hierarchii, w wyniku której powstaje ,polityczność”. Kontrola tego dostępu staje się kluczowym ogniwem powstania wyższej władzy, dla której społeczny kontakt z zewnętrznym światem był absolutnie kluczowy. Stąd, wydaje się istnieć sprzężenie zwrotne między intensyfikacją rolnictwa, nabywaniem bogactwa i powstaniem hierarchii ${ }^{29}$. Według Rosenberga ta ewolucyjna opowieść, która wydaje się zgodna z nierekonstruowaną „wewnętrzną” koncepcją rozwoju, zawiera kluczowe interaktywne ogniwo: zewnętrzny handel ułatwia hierarchię, zaś hierarchia poprzez generowanie stałej potrzeby nowych i prestiżowych dóbr, promuje handel. Jeśli dodamy do tego również interaktywne przyczyny wyrastające ze zmienionej logiki bezpieczeństwa dostrzeżemy, że wewnętrzna struktura tak modelowanego procesu rozwoju (to znaczy powstawania protopaństwa) jest nieuchronnie połączona. Obejmuje ona mechanizmy wyrastające w szczególny sposób z koegzystencji więcej niż jednej społeczności.

Buzan i Little słusznie dowodzą, że model ten ukazuje zarówno, pomijaną w realizmie strukturalnym, rolę jednostkowego poziomu zróżnicowania (hierarchii) w narodzinach anar-

\footnotetext{
${ }^{28}$ J. Rosenberg, Basic..., op. cit., s. 183.

${ }^{29}$ B. Buzan, R. Little, International..., op. cit., s. 153.
} 
chicznej logiki i znaczenie protomiędzynarodowej dynamiki w wyjaśnianiu zmiany społecznej. Jednak w takim ujęciu socjologiczne i protomiędzynarodowe przyczyny pozostają rezydualnie zewnętrzne względem siebie. Według Rosenberga ten brak związku powinien zostać przezwyciężony. Przyczyny te (interaktywna logika społecznej zmiany) widziane poprzez poziom III abstrakcji NIPR są dynamikami zakorzenionymi wyraźnie w przestrzenno-czasowej nierównej i połączonej naturze samego „rozwoju”. W ten sposób naprawiają one w ramach pojedynczej teorii - społeczna teorię stosunków międzynarodowych ${ }^{30}$.

Jednak nawet ten krok według Rosenberga nie jest jeszcze wystarczający, aby dokonać derywacji politycznej wielości z NIPR. Rosenberg dowodzi konieczności wniesienia nierówności i połączoności do samego pojęcia rozwoju. Równocześnie jednak należy dokonać również wniesienia na nowo pojęcia rozwoju w rozważania o nierówności i połączoności. Bez tej operacji inwersji problematyczna linearność klasycznych koncepcji rozwoju zostanie uzupełniona o równie problematyczną różnicę i interakcję per se. Tym samym teza, że socjologiczny rozwój jest zawsze nierówny i połączony będzie zaciemniała równie znaczącą tezę, że to co ukazują te właściwości pozostaje tym niemniej „rozwojem”. Fakt ten wnosi nie mniej znaczące determinanty (wyrastające z osiadłego życia, rolnictwa, formowania państwa, etc.) do argumentu. Wymaga to włączenia abstrakcji NIPR w szerszą koncepcję rozwoju. W odróżnieniu od stanowiska Buzana i Little, ale nie w sprzeczności z nim, włączenie to dostarcza pełniejszego i bardziej zintegrowanego wyjaśnienia politycznej wielości ${ }^{31}$.

Aby zrobić zapowiadany trzeci krok (wyjaśnienie politycznej wielości) spełnić trzeba trzy warunki: 1) wykazać, że NIPR poprzedza międzynarodowość; 2) wykazać, że NIPR odgrywa możliwą do teoretyzowania rolę w jej późniejszym powstaniu i 3) że rola ta ukazuje kluczową charakterystykę politycznej wielości.

Istnienie dwóch pierwszych z tych warunków zostało już wykazane. NIPR (w pierwotnej formie wielości i interakcji w GMZ) poprzedzał powstanie „społeczeństw”. GMZ były jednostkami o wystarczającej wielkości, aby zapewnić najbardziej podstawowe wymogi biologicznej reprodukcji i utrzymania bez potrzeby fundamentalnej i ciągłej symbiozy z sąsiadami. Grupy te były równocześnie czymś więcej niż zwykłym zgromadzeniem jednostek. Zachodziły w nich procesy zróżnicowania i stratyfikacji, które prowadziły do powstania zarówno nowej społecznej przestrzeni ,polityczności” wewnątrz, a w swojej konsekwencji również do powstania bardziej znaczącej dystynkcji między „wewnątrz” i „na zewnątrz”. Tutaj zatem znajdują się socjologiczne źródła międzynarodowości. Jednak żaden z wcześniejszych teoretyków społecznych, także Buzan i Little, nie traktowali sekwencji rozwojowej prowadzącej do takich rezultatów jako zawartej wyłącznie w powstających społeczeństwach. Dla wszystkich wariacje i interakcje między nimi są zarówno implicité konieczne do generowania empirycznej konfiguracji umożliwiającej wprowadzenie tych warunków lub explicité konstytutywną częścią przyczynowych mechanizmów samego rozwoju społecznego. Rozumienie rozwoju jako nierównego i połączonego pozwala na umieszczenie tych czynników w należnym im miejscu w ustanawianej teorii społecznej.

Ostateczny warunek wymaga zatem socjologicznego wyjaśnienia faktu politycznej wielości, a nie tylko wpływu powstania ,polityczności” na formę tej wielości. Zatem, z jednej strony, ponieważ poziom rozwoju wczesnych państw nie pozwalał żadnemu z nich na objęcie całego ludzkiego świata, ich twardniejący podział wewnątrz/na zewnątrz w konieczny sposób

\footnotetext{
${ }^{30}$ J. Rosenberg, Basic..., op. cit., s. 184.

${ }^{31}$ Ibidem, s. 184.
} 
prowadził do ich okrzepnięcia jako osobnych jednostek. Z drugiej strony, ponieważ przyczynowe działanie społecznych stosunków i interakcji, w ramach których one krzepły przekraczało granicę (poprzez wymianę, komunikację i geopolitykę) zasięgu każdej scentralizowanej władzy politycznej, istnienie tych wczesnych państw stymulowało reaktywnie rozwój społecznego zróżnicowania i formowania protopaństw poza nimi samymi, prowadząc do powstawania kolejnych ,„politycznych” jednostek ${ }^{32}$.

Proces taki wydaje się leżeć u podstaw historii narodzin pierwszego znanego nam systemu państw. Sumeryjskie miasta-państwa rozwinęły się w miejscach krzyżowania się wodnych i lądowych sieci handlowych. Chociaż ich środowisko naturalne sprzyjało aktywności rolniczej pozbawione było niezbędnych surowców (drewna, rud metali, kamienia), które były dostępne w syryjskim, anatolijskim i irańskim hinterlandzie pozostającym poza zasięgiem sumeryjskiej ekspansji militarnej, ale nie handlowej. Konsekwencją tego dla hinterlandowych wspólnot było przyspieszenie zachodzących w nich procesów społecznej stratyfikacji. Wyłoniły one liderów kierujących wytwarzaniem dóbr przeznaczonych na eksport do Sumeru i kontrolujących dystrybucję importowanych stamtąd towarów ${ }^{33}$. Z rozwojem rolnictwa proces rozwojowy (społecznego zróżnicowania) wytwarzając ,polityczność” w jednym miejscu generuje ubocznie przyczyny, poprzez które w nierównomierny i interaktywny sposób powstaje wiele jednostek politycznych. Tym samym NIPR jest nie tylko istotą dzisiejszej międzynarodowości, ale także jej ,„przedpotopowym” źródłem ${ }^{34}$.

\section{Społeczna teoria stosunków międzynarodowych: procedura konstruowania teorii}

Problem czy abstrakcja NIPR może pełnić funkcje ogólnej społecznej teorii stosunków międzynarodowych, a więc nie być tylko „teorią polityczną stosunków międzynarodowych”, ale teorią przekraczająca granicę między „,wewnętrzną” i ,międzynarodową” polityką, wymaga poddania jej procedurze konstruowania teorii. Rosenberg sprowadza tę procedurę do trzech najważniejszych kroków. Po pierwsze, sprawdzenia czy ustanawiamy alternatywny wobec dotychczasowych teorii przedmiot badań. Po drugie, sprawdzenia czy identyfikujemy podobne prawom wzorce zachowania w obszarze przedmiotu teorii. Po trzecie, sprawdzenia czy wzorce te poddają się systematycznemu wyjaśnianiu poprzez zawartość teorii ${ }^{35}$.

Przed zastosowaniem tej procedury do abstrakcji NIPR Rosenberg porusza problem prostoty teorii. Prostoty teorii powinniśmy poszukiwać nie w sferze jej zastosowania, ale w jej logicznym centrum. W takim znaczeniu trudno wyobrazić sobie prostszą ideę rozumienia natury rozwoju społeczno-historycznego: rozwój jest inherentnie nierówny i zawsze połączony. Nierówność znajduje wyraz w różnorodnych drogach i różnorodnych jednostkach rozwoju - środowisku geopolitycznym. Połączony rozwój, w którym społeczna reprodukcja jest interaktywna jest konsekwencją tej nierówności. Realizm strukturalny na najwyższym poziomie ogólności wyjaśnia ,jedną wielką rzecz”: powtarzalność wojny. Podobnie abstrakcja NIPR również wyjaśnia jedną wielką rzecz: dlaczego historia nie podąża prostymi liniami (zarówno na poziomie elementów, które wzajemnie oddziałując na siebie decydują o immanentnych logikach własnego rozwoju, jak i na poziomie całości, która w wyniku tych logik

\footnotetext{
32 Ibidem, s. 185.

${ }^{33}$ R. Smith, Premodern trade in world history, Routledge, Abingdon 2009, s. 25.

${ }^{34}$ J. Rosenberg, Basic..., op. cit., s. 185, 187.

35 J. Rosenberg, Anarchy..., op. cit., s. 18.
} 
nabiera kompleksowej wewnętrznej dialektyki rozwoju)? To właśnie istnienie tego rozdziału zawsze było wielką przeszkodą w rozwoju teorii stosunków międzynarodowych.

Wróćmy jednak do pierwszego kroku procedury konstruowania teorii. Czy abstrakcja NIPR pozwala na wyjście stricte międzynarodowej teorii poza analizę struktury geopolitycznej? Zdaniem Rosenberga abstrakcja NIPR pozwala na wskazanie przedmiotu dyscypliny w postaci międzynarodowej struktury społecznej, wykraczającego poza przedmiot określany jako anarchia międzynarodowa.

W drugim kroku, (sprawdzenia czy identyfikujemy podobne prawom wzorce zachowania w obszarze przedmiotu teorii), dowodem na identyfikowanie podobnych prawom zachowań w obszarze przedmiotu teorii jest na przykład wyjaśnienie dlaczego rozprzestrzenianie się industrializacji w Europie nie prowadziło do powstawania „wielu Anglii”, ale do odmiennych francuskich, niemieckich i rosyjskich doświadczeń, których różnice tym niemniej dają się wyjaśnić w oparciu o istniejący wzorzec. W rezultacie rozwój NIPR generuje zarówno struktury rozwoju, jak i struktury geopolityczne.

W trzecim kroku, (sprawdzenia czy wzorce te poddają się systematycznemu wyjaśnianiu poprzez zawartość teorii), Rosenberg sprawdza eksplanacyjne możliwości abstrakcji NIPR jako teorii w odniesieniu do konkretnego historycznego wydarzenia, mianowicie przyczyn wybuchu I wojny światowej. W historiografii debata o przyczynach I wojny światowej, jak wiele innych tego rodzaju debat, odtwarza dominujący sposób postępowania sprowadzający się do rozdziału między czynnikami ,społecznymi” i „międzynarodowymi”. Wyjaśnienia grawitują albo ku poziomowi jednostkowemu (sprzeczności niemieckiego rozwoju społecznego wyjaśniają wojowniczość Rzeszy i w rezultacie wybuch wojny) albo ku poziomowi systemowemu (struktura europejskiego systemu międzynarodowego w 1914 r. wyjaśnia wzrastające trudności w pokojowym zarządzaniu kryzysem). Dlaczego jednak - pyta Rosenberg - jeśli oba rodzaje zjawisk (rozwojowe i międzynarodowe) są połączone w specyficznie międzynarodowych strukturach świata społecznego, nie dysponujemy pojedynczą teorią międzynarodową, która łączyłaby ich znaczenie? Niezdolność ta ma bez wątpienia charakter teoretyczny. Jeśli możemy wskazać pojedynczą ideę, która mogłaby nie tylko wyjaśniać oba typy zjawisk oddzielnie, ale połączyć je w szerszą całość lub strukturę koniecznych stosunków przyczynowej współzależności, to jesteśmy na drodze uzyskania pełniejszej teorii międzynarodowej, która jest z pewnością lepsza niż „pojedyncza” teoria stosunków międzynarodowych.

Rosenberg we wstępnej empirycznej formie ukazuje jak abstrakcja NIPR znajduje zastosowanie do debaty o przyczynach wybuchu I wojny światowej. To empiryczne wyjaśnienie na najbardziej ogólnym poziomie znajduje wyraz w narracji o procesie industrializacji, który rozpoczął się w Wielkiej Brytanii, a następnie szybko rozszerzał się na kontynencie przybierając różne formy w różnych krajach, często łącząc „,stare” i ,nowe” w sprzeczny i destabilizujący sposób. Nieregularność tego postępu generowała serię dramatycznych zmian w równowadze międzynarodowej, zarówno między industrializującymi się państwami, jak i między ich bliższymi i dalszymi peryferiami, prowadząc ostatecznie do ogólnego załamania w sierpniu 1914 r. ${ }^{36}$ Podejście takie zmusza nas także do odrzucenia ugruntowanych w literaturze mitów, na przykład w tym przypadku mitu o scentralizowanych i racjonalnych zachodnich państwach. Za jedno z najbardziej racjonalnych państw w Europie w tym okresie uważa się powszechnie Prusy. Już wielki elektor Fryderyk Wilhelm (1640-1688) zapowiadał znisz-

\footnotetext{
${ }^{36}$ Ibidem, s. 24-27.
} 
czenie władzy junkrów pruskich i zbudowanie własnej „spiżowej suwerenności”. Jednak junkrzy, pruska klasa właścicieli ziemskich, która zdominowała biurokrację państwa nadal traktowała urzędy publiczne jako środek do sprawowania swej prywatnej władzy. W konsekwencji polityka państwa pruskiego, poczynając od polityki podatkowej poprzez handlową do międzynarodowej, warunkowana była interesami tej klasy. System polityczny Prus, a później także zjednoczonych Niemiec był do 1918 r. w znacznym stopniu wypaczony, faworyzując interesy junkrów. Na przykład, mimo iż już w XIX w. (1849) obowiązywało powszechne prawo wyborcze, pruski system trójklasowego głosowania powodował, że polityczne interesy junkrów dominowały. Nawet jeśli trudno uznać za zadawalającą liczbę urzędników fiskalnych przypadających na liczbę mieszkańców we Francji (1:4100), to wydaje się ona imponująca, jeśli porównamy ją z tym samym stosunkiem w Prusach $(1: 38000)^{37}$. Ilustracją nieefektywności pruskiej biurokracji może być fakt, że pruskie państwo nie wiedziało nawet ilu urzędników pracuje na jego rzecz. Michael Mann ocenia tę sytuację jednoznacznie. Jeśli państwo nie może policzyć własnych urzędników trudno uznać je za biurokratyczne. Absurdem jest zatem uważać za takie państwo Prusy ${ }^{38}$. John M. Hobson uważa za swoistą ironię w kontekście przekonania o racjonalności zachodnich państw, że z przedstawioną oceną zgadzał się również Max Weber. Uważał on, że błędy niemieckiej polityki zagranicznej w latach 1900-1918 były bezpośrednim rezultatem faktu, że biurokracja nie była ani wystarczająco racjonalna, ani scentralizowana, ani wreszcie równoważona przez silne społeczeństwo obywatelskie. Biurokracja była zdominowana przez ,irracjonalne” prywatne interesy dominującej klasy właścicieli ziemskich. $\mathrm{Z}$ tego powodu interesy narodowe zostały złożone na militarystycznym junkrowskim ołtarzu w 1914 r. ${ }^{39}$

Jaka teoria może prowadzić do takiej interpretacji? Teoria, która przedstawia wielostronny i interaktywny wymiar społeczno-historycznego rozwoju w taki sposób, że zmienia empiryczną narrację w jej aspekcie socjologicznym i geopolitycznym, i staje się istotna specyfikując przyczynowe mechanizmy procesu historycznego. Taka, która potrafi połączyć w jeden system eksplanacyjny czynniki socjologiczne i międzynarodowe, które inaczej przeciwstawia się sobie w niekonkluzywnych debatach. Taka, która może dokonać tego, ponieważ jest abstrakcją tego co istotne dla „międzynarodowości” jako całości (między-społecznej wielości i interakcji), a nie tylko jednej z jej części, jaką stanowi geopolityka lub ekonomiczna nierówność. Wreszcie teoria, która znajduje się w takiej sytuacji, że może definiować „,międzynarodowość" wewnątrz swojej koncepcji rozwoju społecznego niż ją jej przeciwstawiać ${ }^{40}$.

\section{Summary}

In several papers recently published by the author, the main reference was the theoretical considerations of Justin Rosenberg, in an attempt to show the reasons for the dichotomization of 'internationality' and 'internality,' and the ways of overcoming this dichotomization.

This paper attempts to resolve and conclude these previously discussed issues. On the ground of Rosenberg's theoretical assumptions, the paper answers the questions of where

\footnotetext{
${ }^{37}$ J. M. Hobson, The Eastern Origins of Western Civilisation, Cambridge University Press, Cambridge 2004, s. 286.

${ }^{38}$ M. Mann, The Sources of Social Power, t. 2, Cambridge University Press, Cambridge 1993, s. 390.

39 J. M. Hobson, The Eastern..., op. cit., s. 286.

40 J. Rosenberg, Anarchy..., op. cit., s. 27.
} 
'internationality' originated, and what is a decisive factor for its existence as the dimension of the social world.

The author makes reference to the notion of uneven and combined development as interpreted by J. Rosenberg so as to reconstruct the methods applied in answering the above questions in three stages. Firstly, he discusses the model, allowing a comparison of different methods of combining uneven development with international relations. It emerges that, thus far, all these methods have tended to assume political multiplicity (internationality) rather than explain its existence. Secondly, the author reconstructs the explanations referring to the historical-and-sociological argument presented in the work of Barry Buzan and Richard Little. They place the sources of internationality in the prehistoric transition from a hunter-gatherer existence to an agricultural one, which was connected with processes of social diversification and the formation of proto-states. At first glance, Buzan and Little's explanation seems to make the notion of uneven and combined development redundant. On more detailed analysis, however, 'unevenness' and 'combination' turn out to play a key role in Buzan and Little's empirical argument, albeit not theorized upon. Thirdly, the author of this paper demonstrates how 'unevenness' and 'combination' are necessary elements in processes of social transformation. Thus, he demonstrates that the sources of 'internationality' do come from the uneven and combined nature of historical development. 